\title{
Erratum to: Assessing human-bat interactions around a protected area in northeastern Brazil
}

\author{
Karlla Morganna Costa Rego ${ }^{1}$, Caio Graco Zeppelini2 ${ }^{2 *}$, Luiz Carlos Serramo Lopez \\ and Rômuno Romeu Nobrega Alves ${ }^{3}$
}

\section{Erratum}

An author was unfortunately omitted from the original publication of this article [1]. Luiz Carlos Serramo Lopez has been added as the third author of this article and the Authors' contributions section has been updated accordingly.

\section{Authors' contributions}

KMCR performed the field data collection and wrote the first original manuscript in Portuguese (Master's thesis), CGZ prepared the submission version of the manuscript and carried the taxonomical identifications demanded, LCSL coordinated the research project, performed the original analysis, advised and mentored the original manuscript (Ms. KMCR Master's thesis), RRNA developed the interview protocol, proofed and supervised the manuscript. All authors read and approved the final manuscript.

\section{Author details}

1Programa Regional de Pós-Graduação em Desenvolvimento e Meio-Ambiente - PRODEMA, Universidade Federal da Paraíba, Campus I, Cidade Universitária, João Pessoa 58051-900 PB, Brazil. ${ }^{2}$ Programa de Pós-Graduação em Ciências Biológicas - Zoologia, PPGCB-ZOOLOGIA, Universidade Federal da Paraíba, Campus I, Cldade Universitária, 58051-900 João Pessoa, PB, Brazil. ${ }^{3}$ Departmento de Biologia, Universidade Estadual da Paraíba, Avenida das Baraúnas, 351, Bodocongó, Campina Grande, Paraíba CEP 58109-753, Brazil.

Published online: 29 December 2015

\section{Reference}

1. Costa Rego KM, Zeppelini CG, Serramo Lopez LC, Nobrega Alves RR.

Assessing human-bat interactions around a protected area in northeastern Brazil. J Ethnobiol Ethnomed. 2015:11:80

\footnotetext{
* Correspondence: czeppelini@gmail.com

${ }^{2}$ Programa de Pós-Graduação em Ciências Biológicas - Zoologia, PPGCB-ZOOLOGIA, Universidade Federal da Paraíba, Campus I, Cldade Universitária, 58051-900 João Pessoa, PB, Brazil
}

\section{Submit your next manuscript to BioMed Central and take full advantage of:}

- Convenient online submission

- Thorough peer review

- No space constraints or color figure charges

- Immediate publication on acceptance

- Inclusion in PubMed, CAS, Scopus and Google Scholar

- Research which is freely available for redistribution

Submit your manuscript at www.biomedcentral.com/submit 